\title{
EFFECT OF PLACENTAL "SERUM" IN RHEUMATOID ARTHRITIS*
}

\author{
BY \\ JEROME SIMSON and JOSEPH J. BUNIM \\ From the Department of Medicine and Study Group on Rheumatic Diseases, New York University College \\ of Medicine, and the Third (N.Y.U.) Division Arthritis Clinic of Bellevue Hospital, New York
}

(RECEIVED FOR PUBLICATION JULY 14, 1952)

Aronson, Levy, Besen, and Leff (1952) reported results of the use of placental " serum " in rheumatoid arthritis. $10 \mathrm{ml}$. serum were administered intramuscularly twice weekly, and of 35 patients treated by them, clinical remission (Grade I) occurred in none, moderate improvement (Grade II) in 23, mild improvement (Grade III) in eight, and no improvement (Grade IV) in four. Improvement was noted after the fourth or fifth injection in the 85 per cent. of patients who benefited from the serum, and once improvement had occurred, it was generally sustained as long as therapy was continued. After 10 to 20 weeks of treatment it was possible to reduce the injections to one a week in 25 per cent. of the cases, and in another 25 per cent. injections were discontinued for 3 to 6 months without relapse. In the cases that relapsed, re-treatment , again induced a good response.

In these cases, " improvement" consisted of moderate reduction in stiffness, rest pain, pain on motion, and articular tenderness. There was slight to moderate reduction in joint swelling and moderate increase in muscle strength and joint function in 85 per cent. of the improved patients. The general well-being and appetite of almost all patients improved. It was observed that the better responses took place in the younger age group and in those whose disease was of shorter duration.

\section{Present Investigations}

Serum.-Placental " serum " was made available to us in October, 1951, through the kindness of Dr. Fred Levy, a member of the original group of investigators. This material is obtained from the placenta shortly after delivery. Actually the solution submitted to us was a mixture of serum and blood cells-since the "serum" was never clear and straw-coloured, but contained sediment and became

\footnotetext{
* This work was supported by a grant from the Masonic Foundation for Medical Research and Human Welfare.
}

cloudy and red when shaken. $10 \mathrm{ml}$. of this mixture were injected intramuscularly twice weekly. Initially $0.5 \mathrm{ml}$. procaine was mixed with the "serum" at the time of injection, as recommended, but subsequently this was discontinued without increasing the discomfort of injections.

Material.-Our series consisted of eight patients, five females and three males, seven with rheumatoid arthritis and one with psoriatic arthropathy. Their ages ranged from 24 to 60 years, and the duration of disease from 5 months to 23 years. Only clearly defined cases of rheumatoid arthritis were selected for evaluation.

Each patient was classified according to the criteri of the American Rheumatism Association and examine廷 twice weekly by the same observer for pain on rest of motion, heat, tenderness, redness, swelling, effusion, an range of motion of all joints.

Erythrocyte sedimentation rates were determined at weekly intervals in each case.

Five patients had received gold and two had received ACTH and cortisone at some time prior to treatment.

Dosage.-Patients with rheumatoid arthritis were given injections twice weekly for periods ranging from 8 to 12 weeks. The patient with psoriatic arthropathy, however, received one injection every $48 \mathrm{hrs}$ during the final 4 weeks of a 12-week course. This was done to determine whether increased dosage might be more effective.

All eight patients took salicylates voluntarily during " serum" treatment and the amount ingested was used as an index of response. No other drug was administered.

Results.-Despite apparently adequate therapy, only two of the eight patients responded favourably to placental "serum", the improvement in both being Grade III. The improvement lasted for 14 weeks in one patient, and in the other, who developed a new subcutaneous nodule during the seventh week of therapy, relapse occurred 8 weeks after the injections were discontinued. Four patients failed to improve and two became worse. In two patients who did not benefit from placental " serum", ACTH administration in one and cortisone in the other, brought about moderate 
TABLB

DETAILS OF SEVEN CASES OF RHEUMATOID ARTHRITIS AND ONE OF PSORIATIC ARTHROPATHY

\begin{tabular}{|c|c|c|c|c|c|c|c|c|c|c|}
\hline \multirow{2}{*}{ Cases } & \multirow{2}{*}{ Sex } & \multirow{2}{*}{$\begin{array}{l}\text { Age } \\
\text { (yrs) }\end{array}$} & \multirow{2}{*}{$\begin{array}{c}\text { Duration } \\
\text { of } \\
\text { Disease }\end{array}$} & \multirow{2}{*}{ Stage } & \multirow{2}{*}{$\begin{array}{l}\text { Func- } \\
\text { tional } \\
\text { Class }\end{array}$} & \multicolumn{2}{|c|}{$\begin{array}{l}\text { Sedimentation Rate } \\
\text { mm./hr (Westergren) }\end{array}$} & \multirow{2}{*}{$\begin{array}{l}\text { Duration } \\
\text { of Therapy } \\
\text { (wks) }\end{array}$} & \multirow{2}{*}{$\begin{array}{l}\text { New Joints } \\
\text { affected } \\
\text { during } \\
\text { Treatment }\end{array}$} & \multirow{2}{*}{$\begin{array}{l}\text { Results of Therapy } \\
\text { (Grade I-IV) }\end{array}$} \\
\hline & & & & & & Pre & Post & & & \\
\hline 1. & $\mathbf{F}$ & 55 & 5 mths & II & II & 60 & 53 & 12 & Generalized & Worse (IV) \\
\hline 2. & $\mathbf{M}$ & 53 & 6 mths & II & II & 47 & 44 & 8 & Three & No Improvement (IV) \\
\hline$* 3$ & $\mathbf{M}$ & 28 & 5 yrs & II & III & 30 & 19 & 8 & Two & No Improvement (IV) \\
\hline 4. & $\mathbf{F}$ & 40 & 6 yrs & III & II & 45 & 16 & 9 & One & Mild Improvement (III) \\
\hline 5. & $\mathbf{F}$ & 24 & 9 yrs & $\mathbf{I}$ & $\mathbf{I}$ & 35 & 39 & 10 & None & No Improvement (IV) \\
\hline 6. & $\mathbf{M}$ & 60 & $10 \mathrm{yrs}$ & II & II & 52 & 54 & 9 & Three & Worse (IV) \\
\hline+7 & $\mathbf{F}$ & 55 & 15 yrs & III & III & 72 & 78 & 11 & None & No Improvement (IV) \\
\hline$\mp 8$. & $\mathbf{F}$ & 49 & 23 yrs & III & III & 28 & 89 & 10 & $\begin{array}{l}\text { Fresh Sub- } \\
\text { cutaneous } \\
\text { Nodule }\end{array}$ & Mild Improvement (III) \\
\hline
\end{tabular}

* Case 3 responded subsequently to $20 \mathrm{mg}$. ACTH gel twice daily for one week. At present he is adequately maintained on $20 \mathrm{mg}$. once daily.

$\dagger$ Case 7 (psoriatic arthropathy) showed Grade II response (moderate improvement) to cortisone before and after administration of placental "serum".

$\ddagger$ Case 8 had an exacerbation 8 weeks after therapy was discontinued. At present she is responding to rest in bed alone.

(Grade II) improvement. The results of treatment are summarized in the Table.

The erythrocyte sedimentation rate remained unaltered in five of the eight patients. It fell from 45 to $16 \mathrm{~mm}$./hr in one of the two patients who improved, but was unaffected in the other. In one patient who failed to improve, the rate was reduced from 30 to 19 .

There was no eosinopenic response 4 and 24 hours after the intramuscular injection of $10 \mathrm{ml}$. placental " serum " into a normal control who had responded adequately to an intramuscular injection of $25 \mathrm{mg}$. ACTH.

No local or systemic reactions from the injections were noted at any time.

Contrary to the observations reported by Aronson and others (1952) the age of the patient and duration of disease did not significantly affect the outcome. For example, among the six patients who failed to improve, one was 24 and another 28 years of age. In two other patients who failed to improve, the disease was only of 5 and 6 months' duration respectively, and the former suffered a severe exacerbation during therapy.

\section{Summary}

No benefit was observed in six of eight patients with rheumatoid arthritis treated with placental
" serum". In the two patients who derived mild benefit from the " serum ", subjective improvement was greater than objective. No consistent antirheumatic effect was noted after the use of placental " serum" in this series of patients.

\section{REFERENCE}

Aronson, W., Levy, F., Besen, L. J., and Leff, M. (1952). Amer. J. med. Sci., 223, 144.

Effet du " sérum " placentaire sur l'arthrite rhumatismale RÉSUMÉ

Six sur huit malades atteints d'arthrite rhumatismale n'accusèrent aucune amélioration après le traitement par le "sérum" placentaire. Chez les deux autres une légère amélioration fut plutôt de nature subjective. En somme, dans ce groupe de malades on ne nota aucun effet antirhumatismal appréciable à la suite de l'emploi du "sérum" placentaire.

\section{Efecto del " suero" placentario sobre la artritis \\ Sumario}

De ocho enfermos con artritis reumatoide, seis no acusaron mejoría alguna después del tratamiento con el "suero" placentario. En los demás la mejoría fué más bien subjetiva. En este grupo de enfermos no se notó, pués, efecto antireumático apreciable después del empleo del " suero" placentario. 